\title{
PELATIHAN BUDIDAYA SAYURAN DENGAN TEKNIK VERTIKULTUR DI DESA KECITRAN, BANJARNEGARA
}

\author{
Ridho Ananda ${ }^{\text {) }}$, Atik Febriani ${ }^{2)}$, Auliya Burhanuddin ${ }^{3)}$ \\ ${ }^{1,2}$ Program Studi Teknik Industri, Fakultas Rekayasa Industri dan Desain, Institut Teknologi Telkom \\ Purwokerto \\ ${ }^{3}$ Program Studi Teknik Informatika, Fakultas Informatika, Institut Teknologi Telkom Purwokerto
}

\begin{abstract}
Abstrak
Banyaknya ibu rumah tangga di dusun Kecitran Klampok Banjarnegara membuat kepala desa membentuk kelompok wanita tani (KWT) "Sri Lestari" tahun 2016. Tujuannya memberikan keterampilan bidang pertanian yang mudah diimplementasikan sehingga berpotensi pada penambahan penghasilan di rumah mereka. Namun kegiatan KWT "Sri Lestari" saat ini hanya berupa arisan rutin. Pelatihan mengenai pertanian dilaksanakan hanya satu kali tahun 2018. Kondisi tersebut tentunya disayangkan, dikarenakan ada beberapa teknologi pertanian yang mudah diimplementasikan. Salah satunya yaitu budidaya sayuran dengan teknik vertikultur. Oleh karena itu, diusulkanlah kegiatan program kemitraan bagi masyarakat (PKM) yang bertujuan memberikan pengetahuan bagi KWT "Sri Lestari" melalui pelatihan budidaya sayuran dengan teknik vertikultur. Pelatihan ini terdiri dari lima kegiatan yakni (1) pengenalan teknik vertikultur, (2) persiapan lahan, (3) pembuatan media vertikultur, (4) pembuatan bibit sayuran, dan (5) penanaman bibit sayuran pada media vertikultur. Hasil penilaian kinerja KWT menunjukkan bahwa secara umum media vertikultur sudah baik dan cara penanaman benar. Kuesioner pelatihan juga menunjukkan $85 \%$ lebih responden memahami materi dan instruksi dari narasumber.
\end{abstract}

Kata Kunci: Banjarnegara, sayuran, kelompok wanita tani, teknologi pertanian, vertikultur

\begin{abstract}
A high number of housewives in Kecitran village Klampok-Banjarnegara caused headman to establish women farmers group (KWT) "Sri Lestari" for them in 2016. Its purpose to provide agricultural skills that are easily implemented so it will be increase earn. But, its activities are currently just about social gathering. Training in agriculture was only held once in 2018. That condition is certainly not good, because there are several agricultural techniques that are easy to be implemented, one of them is vertikultur technique. Therefore, it has been proposed a partnership program for community (PKM) with purpose to give knowledge for that group through training vegetable cultivation by using vertikultur techniques. There are five of activities in that training namely (1) introduction of vertikultur technique, (2) preparation of the land, (3) making vertikultur media, (4) making vegetable seeds, and (5) planting vegetable seeds on vertikultur media. The training results showed that media of vertikultur arranged were adequate and the planting of vegetable seeds in there were correct. Training questionnaire also showed that more than $85 \%$ respondents understood learning and instructing from tutors.
\end{abstract}

Keywords: Banjarnegara, Vegetables, women farmers group, agricultural techniques, vertikultur, vegetables seeds 


\section{PENDAHULUAN}

Kecitran Purwareja Klampok Banjarnegara merupakan dusun yang terletak di ujung kabupaten Banjarnegara dan dekat dengan perbatasan kabupaten Banyumas dan perbatasan kabupaten Purbalingga. Jarak dusun ini dengan pusat pemerintahan kabupaten Banjarnegara sekitar $33 \mathrm{~km}$. Dusun Kecitran berpenduduk sekitar 6.351 jiwa dengan angkatan kerja sejumlah 4.878 (76.5\%) jiwa. Gambar 1 memberikan informasi data 10 urutan tertinggi kelompok pekerjaan penduduk dusun Kecitran yang masuk angkatan kerja dengan jumlah 4.428 jiwa atau 93,64\% dari seluruh angkatan kerja. Dari gambar tersebut diketahui bahwa ibu rumah tangga $(23,28 \%)$, pelajar $(22,29 \%)$, karyawan swasta $(15,25 \%)$, dan buruh harian lepas $(13,74 \%)$ merupakan pekerjaan yang cukup dominan di dusun Kecitran.

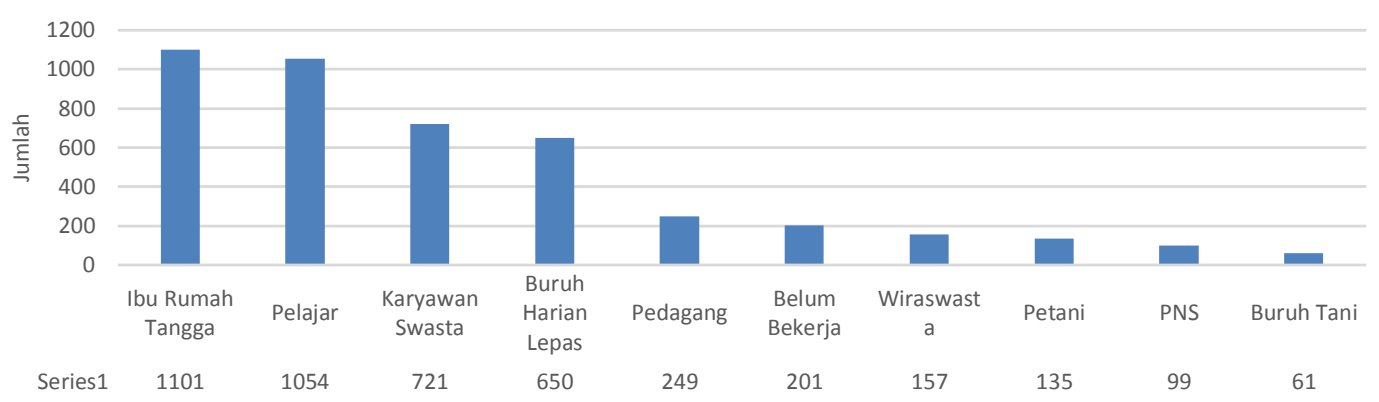

Gambar 1 Distribusi pekerjaan penduduk dusun Kecitran pada umur angkatan kerja

Visi dari dusun Kecitran sendiri yakni "Terwujudnya Desa Kecitran Mandiri dan Sejahtera". Untuk mewujudkan visi tersebut, kepala desa Kecitran melakukan beberapa upaya, salah satunya yaitu membentuk kelompok wanita tani (KWT) "Sri Lestari" Dusun Kecitran pada tahun 2016. Kelompok tersebut tidak hanya beranggotakan ibu-ibu yang berprofesi sebagai petani, namun juga mengikutsertakan mereka yang hanya berprofesi sebagai ibu rumah tangga. Harapan terbentuknya KWT "Sri Lestari" ialah memiliki keterampilan di bidang pertanian yang dapat diimplementasikan di sekitar lingkungan tempat tinggal anggota-anggotanya sehingga dapat menjadi tambahan penghasilan yang berpotensi pada peningkatan kesejahteraan. Kegiatan rutin KWT "Sri Lestari" saat ini masih berupa simpan pinjam dan arisan antar anggota sebagaimana ditunjukkan pada Gambar 2, sedangkan kegiatan dibidang pertanian baru dilaksanakan satu kali dengan pemateri dari Badan Latihan Kerja (BLK) berupa penyemaian dan penanaman cabai di polibag tahun 2018. Kondisi tersebut tentunya cukup disayangkan karena banyak teknologi pertanian yang tentunya dapat mereka pelajari, salah satunya yaitu vertikultur.

Vertikultur merupakan metode bercocok tanam dalam susunan vertikal ke atas menuju ruang udara bebas dengan susunan media tanam yang juga disusun secara vertikal (Nurmawati 2016). Teknik vertikultur memiliki nilai estetika dan dapat diimplementasikan di pekarangan rumah sehingga dapat dijadikan kegiatan tambahan bagi ibu-ibu rumah tangga. Media tanam yang digunakan dalam teknik vertikultur dapat berupa media cair maupun padat seperti kompos, pasir, sekam, dan tanah steril. Di beberapa negara maju, penggunaan vertikultur telah dipadukan dengan sistem hidroponik maupun aeroponik. Media tanam dapat ditampung dalam kaleng-kaleng, paralon pvc, 
bambu atau papan kayu yang disusun secara bertingkat. Bentuk atau susunan vertikultur tentunya harus disesuaikan dengan jenis dan bentuk tanaman agar tanaman tersebut memperoleh sinar matahari. Hampir semua jenis sayuran dapat dibudidayakan menggunakan cara ini dengan masa panen bekisar antara 2-3 bulan. Teknik vertikultur telah diimplementasikan di beberapa wilayah antara lain di Tegal Rejo Medan pada kelompok ibu-ibu Aisyiyah (Manik et. Al, 2018), di Tasikmalaya pada KWT Zahra (Isnaeni dan Yunita, 2019), dan yang terbaru di kota Bandung (Kusumo et. Al, 2020).

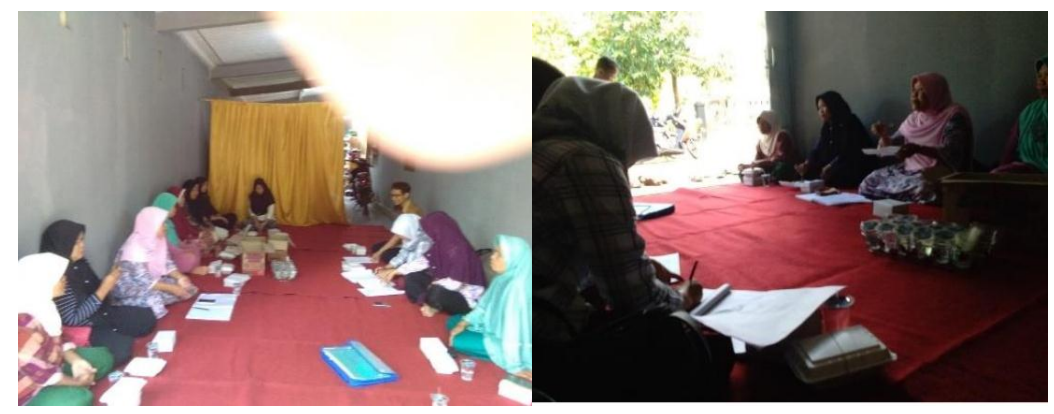

Gambar 2 Arisan Rutin KWT "Sri Lestari”

Berdasarkan uraian tersebut, maka penerapan teknologi vertikultur akan menjadi hal yang sangat bermanfaat bagi anggota KWT "Sri Lestari" desa Kecitran Purwareja Klampok Banjarnegara baik dari sisi tambahan penghasilan maupun sisi estetika. Hanya saja, belum dikenalnya teknik vertikultur menjadikan mereka tidak dapat mengimplementasikan teknik tersebut di wilayah pekarangan mereka. Melihat fakta-fakta tersebut, maka diusulkanlah kegiatan program kemitraan bagi masyarakat (PKM) yang bertujuan memberikan pengetahuan teori dan praktik bagi anggota KWT "Sri Lestari" mengenai teknik vertikultur melalui pelatihan budidaya sayuran dengan teknik vertikultur.

\section{METODE PELAKSANAAN}

Setelah berdiskusi dengan ketua kelompok KWT "Sri Lestari” maka diputuskan pelatihan budidaya sayuran dengan teknik vertikultur dilaksanakan di balai desa. Metode yang digunakan dalam penyampaian materi ialah metode ceramah, diskusi, dan praktik. Kedua metode tersebut diimplementasikan dalam beberapa kegiatan yakni (1) pengenalan teknik vertikultur, (2) persiapan lahan, (3) praktik pembuatan media vertikultur dengan pvc, (4) praktik pembuatan bibit sayuran pada traypot atau media lain, dan (5) penanaman bibit sayuran pada media vertikultur. Sedangkan metode pelatihan secara umum ditunjukkan Gambar 3.
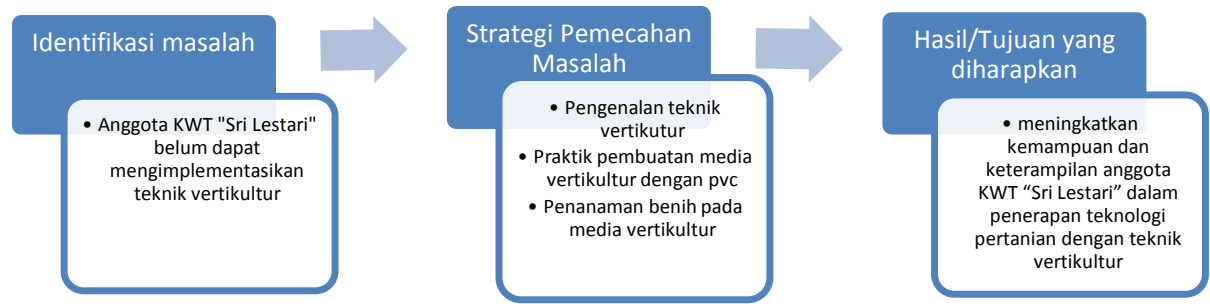

Gambar 3 Diagram alir metode pelaksanaan pelatihan teknik vertikultur 


\section{HASIL DAN PEMBAHASAN}

Kelompok Wanita Tani "Sri Lestari” merupakan kelompok KWT Dusun Kecitran yang awal terbentuknya hanya beranggotakan 20 orang, sekarang anggota dari KWT tersebut sebanyak 30 orang, didominasi oleh ibu-ibu rumah tangga yang tersebar di $5 \mathrm{RW}$ Dusun Kecitran. Peta wilayah Dusun Kecitran ditunjukkan oleh Gambar 4. Sebagaimana yang telah diuraikan, masih terbatasnya kemampuan anggota KWT yang berkaitan dengan teknologi pertanian menyebabkan penggunaan sumber daya di sekitar rumah mereka belum optimal. Oleh karena itu, pelatihan teknik vertikultur ini dilakukan untuk memberikan keterampilan terkait metode vertikultur sehingga bisa mengoptimalkan sumber daya di sekitar rumah mereka. Hasil dari pelaksanaan pelatihan ini diuraikan dalam lima pembahasan yakni (1) pengenalan teknik vertikultur, (2) persiapan lahan, (3) praktik pembuatan media vertikultur dengan pvc, (4) praktik pembuatan bibit sayuran pada tray pot atau media plastik $1 / 4 \mathrm{~kg}$, dan (5) penanaman bibit sayuran pada media vertikultur.

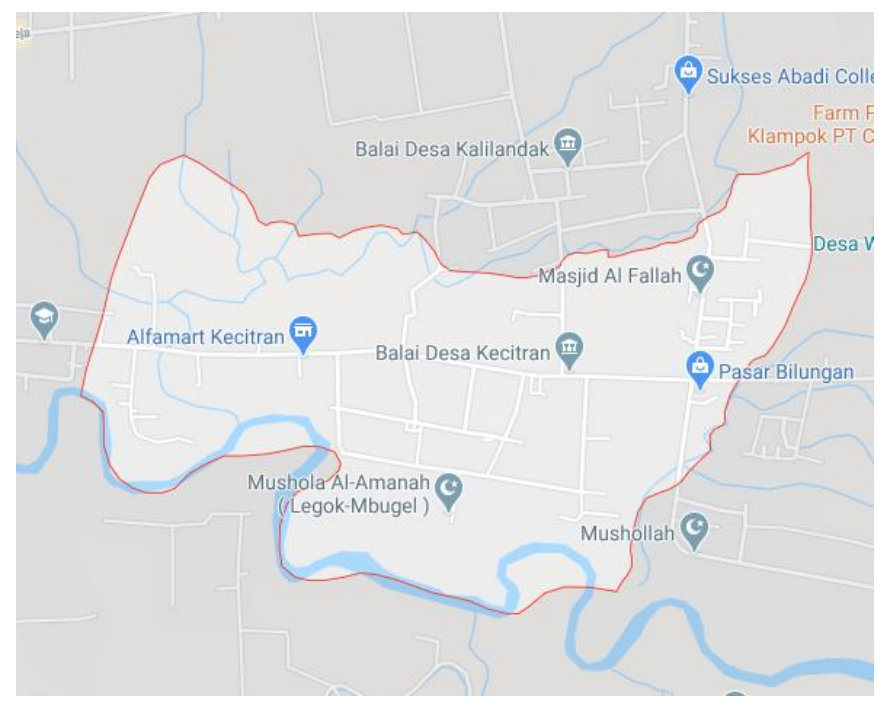

Gambar 4 Peta wilayah Dusun Kecitran Purwareja Klampok Banjarnegara

\subsection{Pengenalan Teknik Vertikultur}

Pengenalan teknik vertikultur merupakan kegiatan penyampaian materi tentang teori-teori vertikultur kepada KWT "Sri Lestari” untuk memberikan bekal pengetahuan sebelum melakukan praktik. Kegiatan ini dilaksanakan pada tanggal 5 Agustus 2019 pukul 13.00 s.d. 15.00 WIB dengan dihadiri 29 anggota KWT "Sri Lestari". Materi disampaikan dengan metode ceramah dan diskusi yang didalamnya memuat (1) pengertian teknik vertikultur dan manfaatnya, (2) alat dan bahan yang dibutuhkan pada teknik vertikultur, (3) cara-cara pembuatan media vertikultur, (4) bibit sayuran yang dapat ditanam pada media vertikultur, (5) teknik penanaman bibit pada media vertikultur. Materi disampaikan secara ringkas dalam durasi satu jam, satu jam berikutnya digunakan untuk diskusi dan tanya jawab untuk menghidupkan suasana. Anggota-anggota KWT "Sri Lestari" cukup antusias dalam mengikuti kegiatan ini, terlihat dari aktivitas diskusi yang ternyata melebihi durasi waktu yang diperkirakan. Gambar 5 menunjukkan dokumentasi kegiatan pengenalan teknik vertikultur. 


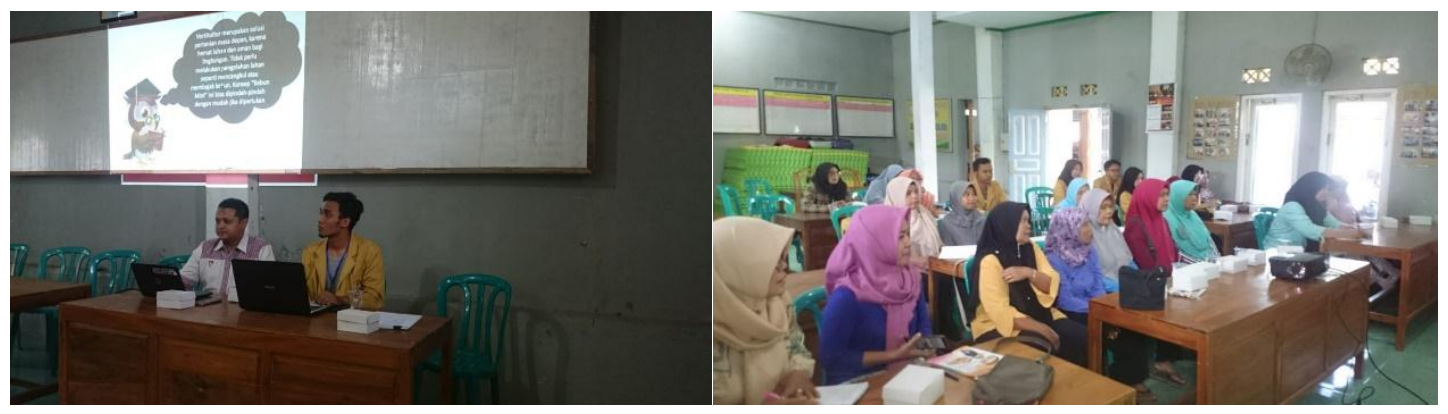

Gambar 5 Kegiatan pembelajaran teknik vertikultur KWT "Sri Lestari”

\subsection{Persiapan Lahan}

Persiapan lahan dilakukan setelah diputuskannya balai desa sebagai tempat praktik dari pelatihan teknik vertikultur. Persiapan lahan ini dilakukan awal bulan September 2019 di pekan minggu pertama. Hasil yang diperoleh dari persiapan lahan ini antara lain (1) diperoleh gambaran tempat praktik pelatihan metode vertikultur, (2) diperolehnya titik-titik lokasi praktik pembuatan media vertikultur, praktik pembuatan bibit sayuran, dan praktik penanaman bibit sayuran pada media vertikultur, (3) dilakukannya pembersihan lokasi dari barang-barang yang dapat mengganggu pelaksanaan pelatihan.

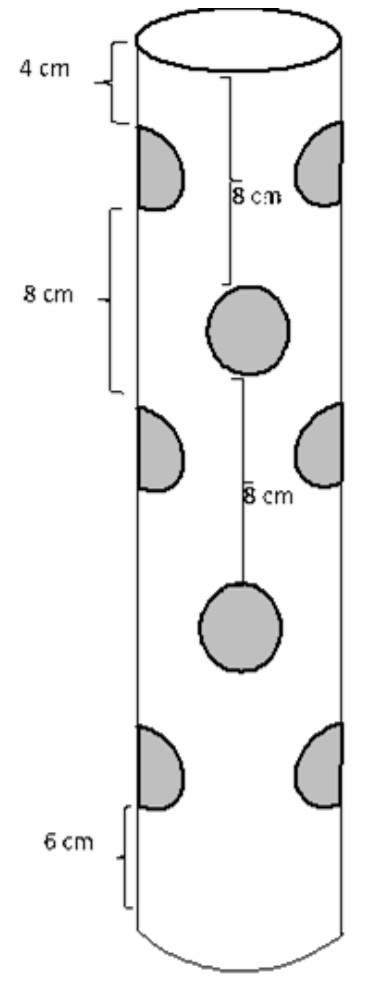

(a)
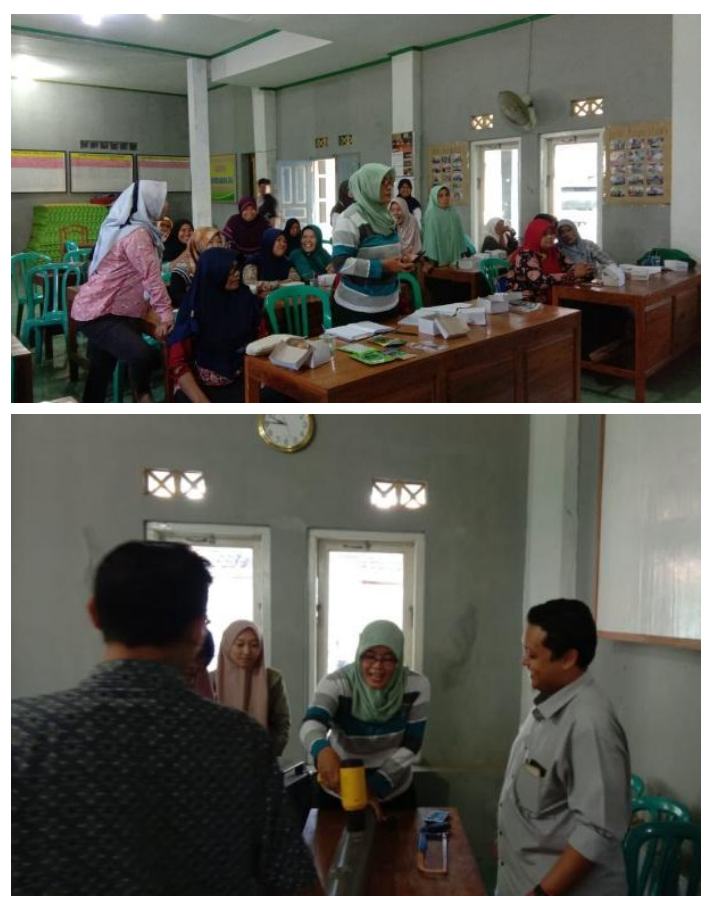

(b)

Gambar 6 (a) Sketsa media tanam vertikultur dengan pvs dan (b) dokumentasi kegiatan praktik pembuatan media vertikultur 


\subsection{Praktik Pembuatan Media Vertikutur dengan pvc}

Praktik pembuatan media vertikultur dilakukan pada hari Jumat tanggal 20 September 2019 pukul 13.00 s.d. 15.00 WIB di balai desa Kecitran. Sejumlah 26 anggota KWT "Sri Lestari" hadir pada kegiatan ini. Alat dan bahan yang dibutuhkan pada kegiatan ini ialah (1) PVC 4" yang telah dipotong dengan ukuran panjang 50 cm, (2) Heat gun kapasitas minimal 400 watt, (3) Botol sirup, (4) Gergaji besi, (5) Spidol, (6) Meteran. Lubang-lubang yang dibuat pada $P V C$ dibuat dalam empat sisi yaitu sisi depan, belakang, samping kanan, dan samping kiri dengan susunan zigzag dimana lubang paling bawah memiliki jarak minimal $6 \mathrm{~cm}$ dengan tanah. Sketsa dari media tanam vertikultur dengan paralon ditunjukkan pada Gambar 6a.

Pada kegiatan ini, hanya beberapa perwakilan anggota KWT yang melakukan praktik secara langsung dikarenakan keterbatasan waktu. Pvc yang disediakan untuk pelatihan sejumlah 30 potong yang memang dikhususnya agar semua anggota melakukan praktik. Sehingga bagi anggota yang belum praktik pada kegiatan ini, mereka melakukan praktik mandiri di balai desa dengan alat dan bahan yang telah dititipkan di balai desa. Pondasi untuk berdirinya media vertikultur dibuatkan oleh tukang yang merupakan penduduk dusun Kecitran. Dokumentasi hasil pembuatan media vertikultur dan proses pembuatan pondasi ditunjukkan Gambar 7.

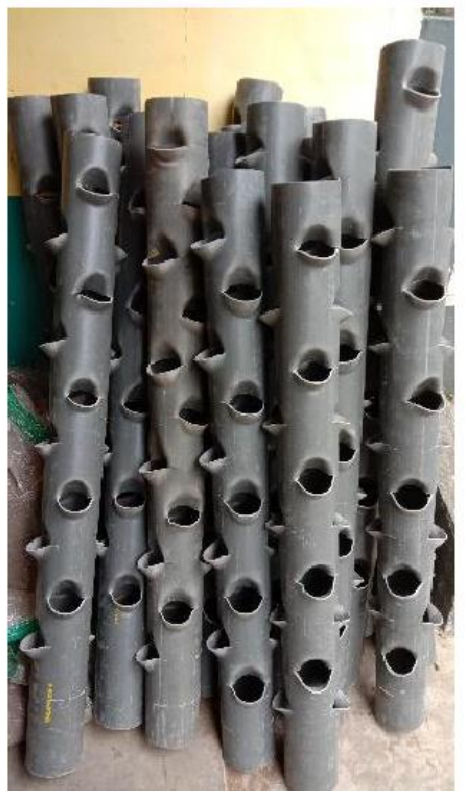

(a)

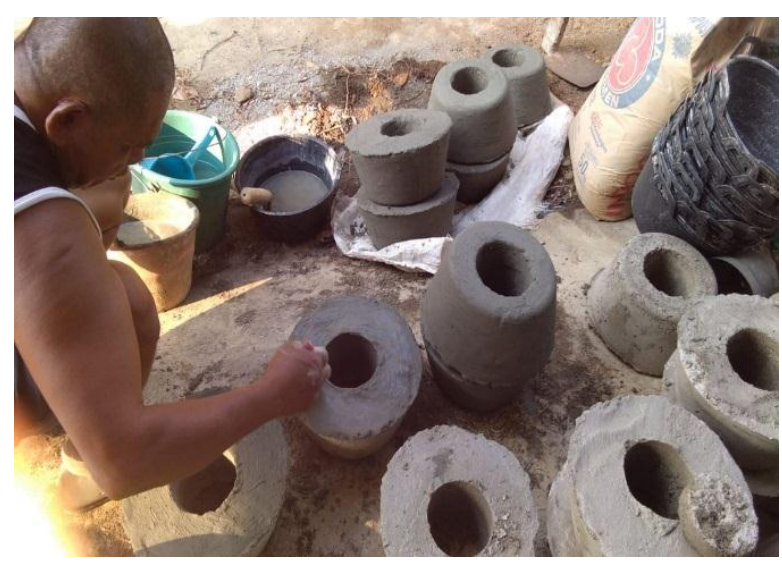

(b)

Gambar 7. (a) Sketsa media tanam vertikultur dengan pvs dan (b) dokumentasi kegiatan praktik pembuatan media vertikultur 


\subsection{Praktik Pembuatan Bibit Sayuran pada Traypot atau Media Lain}

Praktik pembuatan bibit sayuran dilakukan di samping balai desa Kecitran. Alat dan bahan yang diperlukan dalam proses pembibitan antara lain (1) tray pot, (2) plastik $1 / 4 \mathrm{~kg}$, (3) polibag sedang, (4) benih sayuran, (5) tanah, (6) pasir, (7) kompos, (8) sekam, (9) penyiraman, dan (10) sekop. Benih yang disemai antara lain benih kangkung, cabai, selada, dan kacang panjang. Jumlah bibit keseluruhan yang dibuat sebanyak 1200 benih dengan harapan setiap lubang dari media vertikultur akan memperoleh paling banyak 2 benih. Pembibitan dilakukan secara mandiri oleh anggota-anggota KWT "Sri Lestari” dikarenakan sebagian besar dari anggota sudah terbiasa melakukan penyemaian benih menjadi bibit tanaman. Hasil dari pembibitan tanaman dapat dilihat pada Gambar 8.
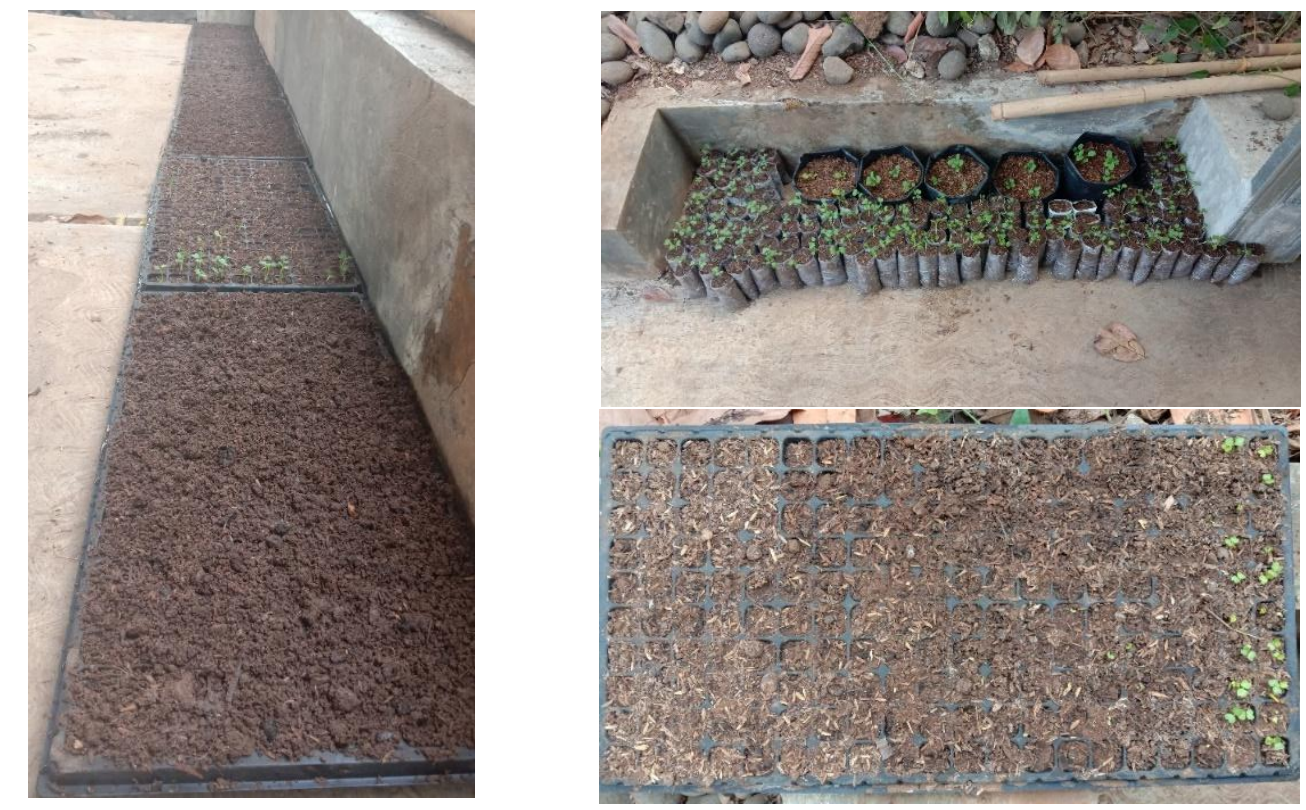

Gambar 7 Dokumentasi pembibitan benih sayuran

\subsection{Penanaman Bibit Sayuran pada Media Vertikultur}

Penanaman bibit pada media vertikultur dilaksanakan pada hari Rabu tanggal 23 Oktober 2019 di Balai Dusun Kecitran. Kegiatan ini dihadiri oleh 27 anggota KWT "Sri Lestari". Pada kegiatan ini, seluruh peserta mula-mula diberi pengantar sedikit mengenai pengisian media vertikultur dengan tanah dan penanaman bibit pada media tersebut. Tanah yang akan digunakan untuk mengisi media vertikultur telah disiapkan sebelumnya sehingga kegiatan ini dapat lebih fokus pengisian media vertikultur dan penanaman bibit sayuran pada media vertikultur. Setelah disampaikan pengantar, selanjutnya seluruh anggota KWT "Sri Lestari” melakukan praktik di belakang balai desa Dusun Kecitran sesuai dengan instruksi yang telah disampaikan. Karena keterbatasan waktu, untuk kegiatan praktik penanaman bibit sayuran pada media vertikultur hanya dilakukan pada sepuluh media vertikultur, sehingga anggota KWT "Sri Lestari" dijadikan berkelompok-kelompok dengan anggota kelompok paling banyak 3 orang. Seluruh kelompok cukup antusias dalam 
melakukan praktik penanaman bibit sayuran di media vertikultur. Dokumentasi dari kegiatan ini ditunjukkan pada Gambar 10.

Setelah beberapa kegiatan terlaksana, selanjutnya dilakukan proses penilaian hasil kerja dari anggota-anggota KWT "Sri Lestari" oleh pejabat Badan Latihan Kerja Pertanian Klampok. Penilaian dilakukan pada minggu ketiga bulan Desember 2019 bersamaan dengan kunjungan pejabat BLK Pertanian ke balai desa Kecitran dalam rangka menyampaikan kegiatan-kegiatan pertanian yang akan dilaksanakan di awal tahun 2020. Media yang dinilai ialah sepuluh media teknik vertikultur yang telah ditanami bibit sayuran. Hasil dari penilaian menunjukkan secara garis besar media vertikultur yang dibuat sudah baik dan cara penanaman sudah benar.

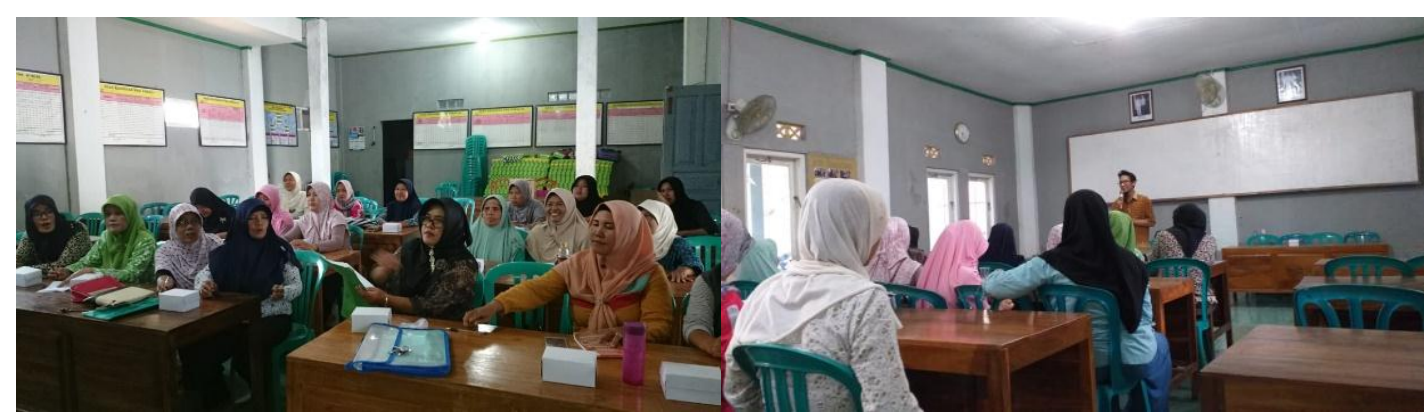

Gambar 8 Materi pengantar sebelum praktik penanaman bibit sayuran pada media vertikultur
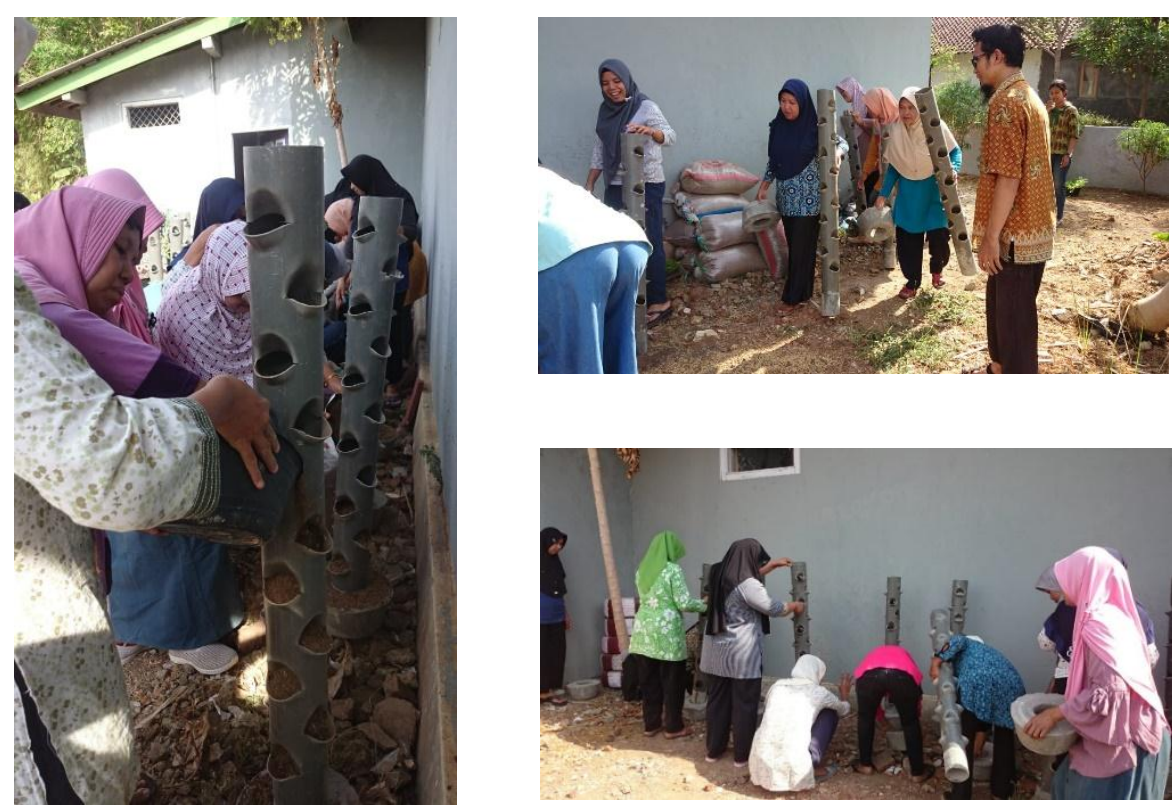

Gambar 9 Kegiatan pengisian media vertikultur dengan tanah

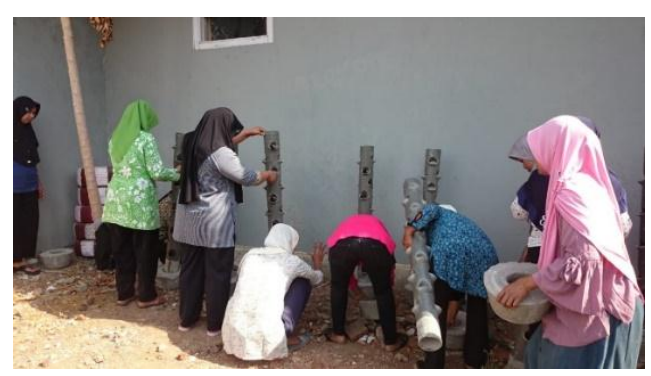



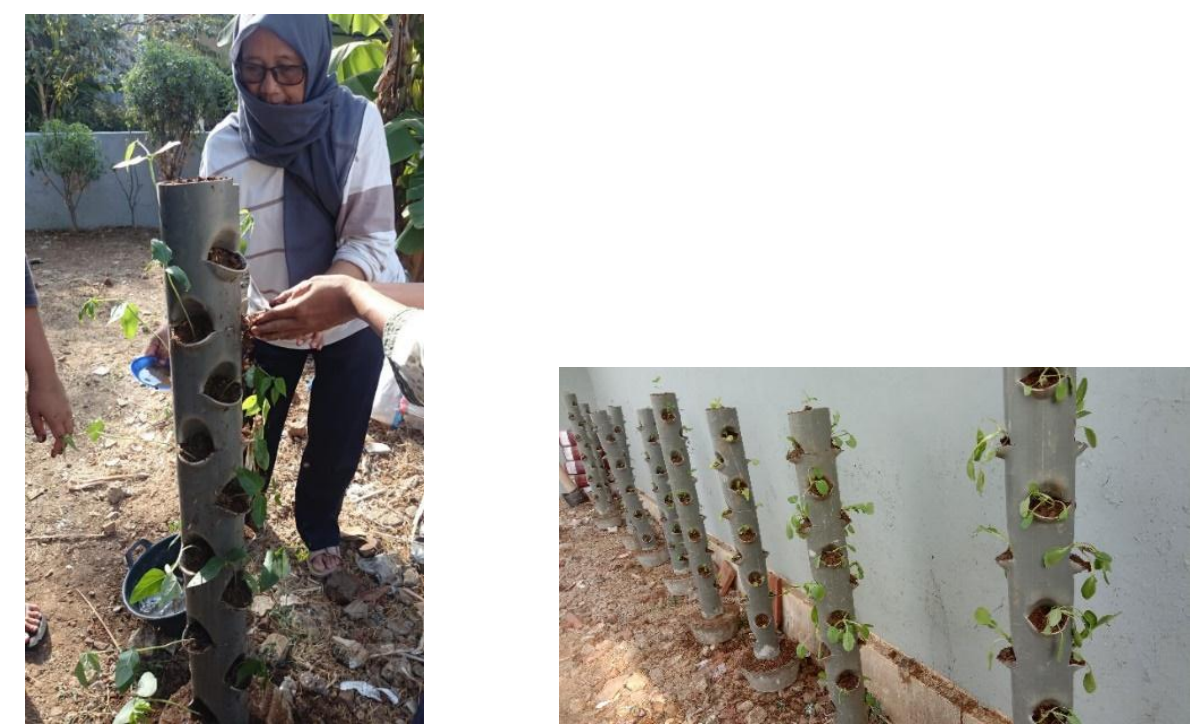

Gambar 10 Kegiatan penanaman bibit sayuran pada media vertikultur

Setelah beberapa kegiatan terlaksana, selanjutnya dilakukan proses penilaian hasil kerja dari anggota-anggota KWT "Sri Lestari" oleh pejabat Badan Latihan Kerja Pertanian Klampok. Penilaian dilakukan pada minggu ketiga bulan Desember 2019 bersamaan dengan kunjungan pejabat BLK Pertanian ke balai desa Kecitran dalam rangka menyampaikan kegiatan-kegiatan pertanian yang akan dilaksanakan di awal tahun 2020. Media yang dinilai ialah sepuluh media teknik vertikultur yang telah ditanami bibit sayuran. Hasil dari penilaian menunjukkan secara garis besar media vertikultur yang dibuat sudah baik dan cara penanaman sudah benar.

Anggota-anggota KWT "Sri Lestari” juga diwajibkan mengisi kuesioner terkait kegiatan pelatihan yang telah dilakukan. Secara garis besar, hasil kuesioner menunjukkan $85 \%$ lebih responden memahami materi dan instruksi dari narasumber. Mereka juga meminta keberlanjutan kegiatan dengan teknik-teknik teknologi pertanian yang lain untuk meningkatkan keterampilan anggota KWT "Sri Lestari”.
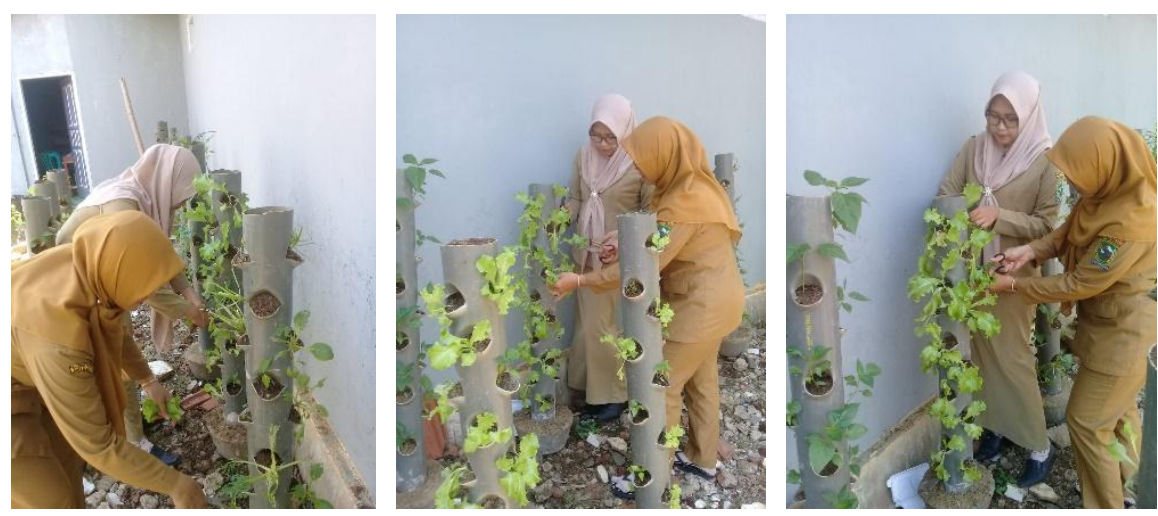

Gambar 11 Penilaian oleh pejabat Badan Latihan Kerja Pertanian Klampok Banjarnegara 

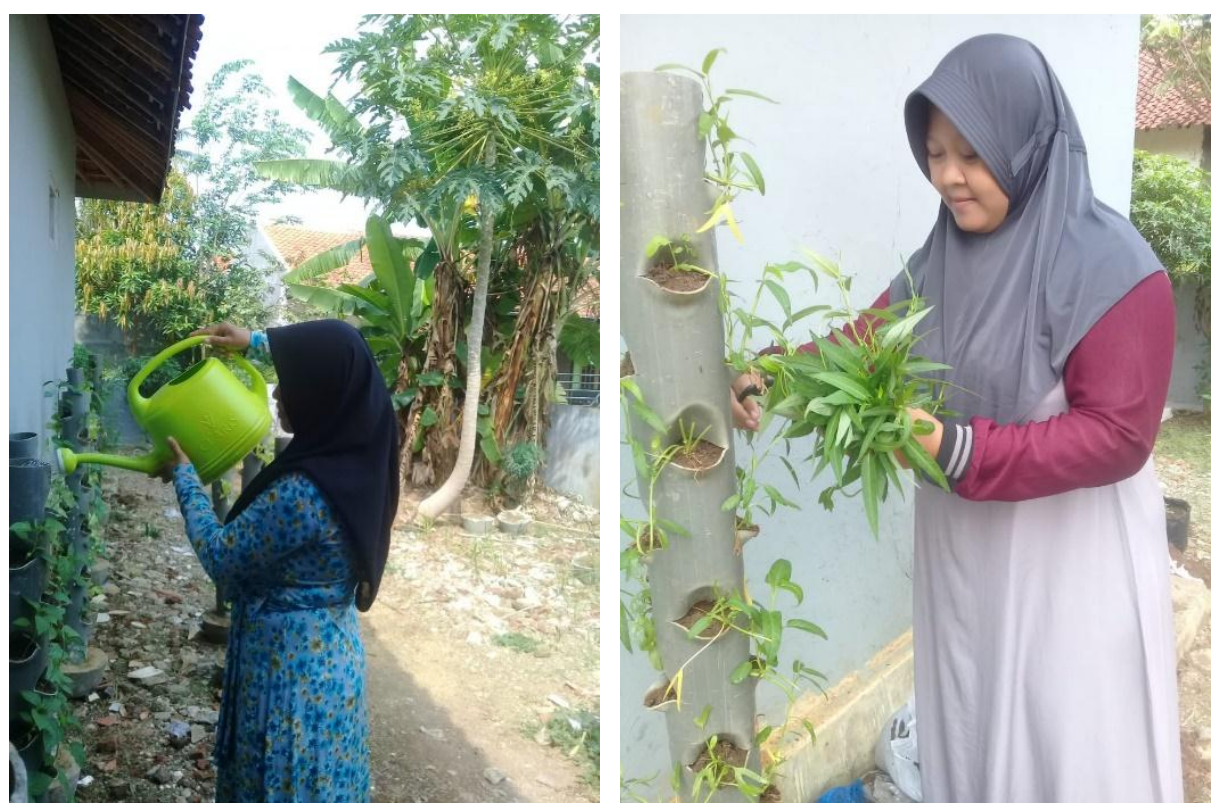

Gambar 12 Perawatan dan pemanenan sayuran pada media vertikultur

\section{SIMPULAN}

Pelatihan budidaya sayuran dengan teknik vertikultur telah dilaksanakan pada KWT "Sri Lestari" dengan lima kegiatan yang melibatkan hampir seluruh anggotanya. Hasil kinerja penanaman sayuran dari anggota-anggota KWT "Sri Lestari" mendapatkan apresiasi yang cukup baik dari pejabat BLK Pertanian Klampok. Hasil survei juga menunjukkan bahwa materi yang disampaikan oleh narasumber dapat diterima oleh sebagian besar anggota KWT dan mereka mengharapkan adanya keberlanjutan kegiatan.

Penulis menyampaikan terima kasih kepada Lembaga Penelitian dan Pengabdian Masyarakat (LPPM) Institut Teknologi Telkom Purwokerto yang telah memberikan dukungan berupa dana yang diperoleh penulis pada hibah internal pada skema Program Kemitraan bagi Masyarakat (PKM) tahun 2019.

\section{DAFTAR PUSTAKA}

Isnaeni, S., Yunita R. 2019. Adopsi teknologi vertikultur skala rumah tangga pada beberapa jenis sayuran di desa Parakannyasag Tasikmalaya. Journal of Empowerment Community. 1(1), 27-32.

Kusumo, R. A. B., Sukayat Y., Heryanto M. A., Wiyono S. N. 2020. Budidaya sayuran dengan teknik vertikultur untuk meningkatkan ketahanan pangan rumah tangga di perkotaan. Dharmakarya: Jurnal Aplikasi Ipteks untuk Masyarakat, 9(2). 89-92.

Manik, J. R., Alqamari M., Hanif A. 2018. Usaha pemanfaatan lahan pekarangan budidaya tanaman sayuran secara vertikultur pada kelompok ibu-ibu Aisyiyah. Jurnal Prodikmas: Hasil Pengabdian Kepada Masyarakat, 3(1), 37-44.

Nurmawati, S. K. 2016. Vertikultur media pralon sebagai upaya memenuhi kemandirian pangan di wilayah Peri Urban kota Semarang. Jurnal Pendidikan Sains, 4(2),19-25. 